\title{
Comparative Study of Damper Effects of Steering Tail Fin Shapes: Part II
}

\author{
Lusiani $^{*}$, Dhimas Satria ${ }^{1}$, A B Rismawan ${ }^{2}$, Erwin $^{1,2}$ \\ ${ }^{1}$ Mechanical Engineering Departement, Universitas Sultan Ageng Tirtayasa Cilegon, Indonesia. \\ ${ }^{2}$ Renewable Energy Design Laboratory, Engineering Faculty Universitas Sultan Ageng Tirtayasa Cilegon, Indonesia \\ *Corresponding author. Email: rina_lusiani@untirta.ac.id
}

\begin{abstract}
The need for the development of the guide fin design that will be used in vertical double shaft wind turbines, the development of the directional tail fins are used to increase the efficiency of the wind turbine. By using a ratio of 1.4 and the area being scaled to $0.042 \mathrm{~m} 2$. The purpose of this research is to make a prototype scale model of the fin, make the fin mount, and determine the design of the guiding tail fin based on its damping effect. The testing process is carried out in a wind tunnel with a test speed of $1 \mathrm{~m} / \mathrm{s}-5 \mathrm{~m} / \mathrm{s}$ with test angles of $5^{\circ}, 10^{\circ}, 15^{\circ}, 20^{\circ}, 25^{\circ}$, and 30 . The testing process is performed using a video recording with slow-motion mode, which will be tracked on the tracker software, later producing a graph to determine the tail fin with the best attenuation. From the test results, it is found that the $1 \mathrm{~A}$ Single fin is the best fin based on its damping effect with an average number of waves at each speed and also an angle of release of 1.1 waves, an average amplitude of $0.014591609 \mathrm{~m}$, and a damping time of $16.16321429 \mathrm{~s}$.
\end{abstract}

\section{Keywords: Damper, Steering Tail, Wind Turbine, Fin Shapes}

\section{INTRODUCTION}

In a previous study, research was conducted on the guiding tail fin of wind turbines, where the first design of the fin with a rectangular shape was studied befor (2019) where the research aimed to design the guiding tail fin and then the performance of the wind turbine was tested after being given the turbine steering tail fin. Wind, the shape used in this study is rectangular with a cross-sectional area of fins based on calculations of $0.06 \mathrm{~m} 2$, and an actual cross-sectional area of fins is $0.219 \mathrm{~m} 2$. However, in this study, the performance of the wind turbine has not been maximized [1].

Furthermore, this research was continued with the design of the V.2 guiding tail fin with its structure (2019), which was used on the Vertical Axis Wind Turbine (VAWT) to restore the Omni-directional force [2], the dimensions used as the cross-sectional area of $0.126 \mathrm{~m} 2$ and the aspect ratio of 1.4. However, this study needs to develop the fin structure and the less-than-optimal wind turbine performance [1].

Because there are several shortcomings in previous studies that cause the turbine performance to be less than optimal, the development of a wind turbine guide tail fin is carried out which aims to create a wind turbine prototype model and determine the shape of the best wind turbine steering tail fin which can later be applied to wind turbines and increase the efficiency of the wind turbine. Turbine performance is based on the damping effect by using wind tunnel media to see the response of the fins based on wind direction [3]. The dimensions used for the fin area are $0.042 \mathrm{~m} 2$, and the aspect ratio is 1.4. The fin shape used is based on the literature sought in the form of 1A, 3A, KMNI, Shark and Airplane. The research gap in this study is the testing on wind tunnels which was not carried out in previous studies. The fin testing in the wind tunnel aims to see the response of each fin shape before the manufacturing process for the fins will be used directly on the turbine [1].

\section{METHODS}

In this study, developed the tail fin guiding the wind turbine, which had previously been investigated. This study aimed to determine the best type of fin based on the damping effect. The aerodynamic testing process used a wind tunnel by utilizing a camera with slow-motion mode which will later be used for analysis. Using a camera with the slow-motion mode is intended to see the 
Table 1. Fin design

\begin{tabular}{|c|c|c|}
\hline No & Fin Shape & Description \\
\hline 1 & & $\begin{array}{l}\text { The design of this fin is based on research by Venkatesh Singamsitty, Hong Zhou. } \\
\text { With fin-type } 1-A \text { on the journal[ㅁ]. }\end{array}$ \\
\hline 2 & & $\begin{array}{l}\text { The design of this fin is based on research by Venkatesh Singamsitty, Hong Zhou. } \\
\text { With 3-A fin-type on journal[]]. }\end{array}$ \\
\hline 3 & & $\begin{array}{l}\text { The design of this fin is based on the research of Y Yulianto*, E Mandayatma and B } \\
\text { Priyadi from the State Polytechnic of Malang. With a type of fin inspired by shark } \\
\text { fins[7]. }\end{array}$ \\
\hline 4 & & $\begin{array}{l}\text { The fin design is based on research by } \mathrm{J} \text { Wieringa of the Royal Netherlands } \\
\text { Meteorological Institute[]. }\end{array}$ \\
\hline 5 & & $\begin{array}{l}\text { The design of this fin is based on the research of Exwan Rahmawan, Gaguk } \\
\text { Jatisukamto from the University of Jember, who discussed airplanes and inspired the } \\
\text { use of a guiding tail fin[9]. }\end{array}$ \\
\hline
\end{tabular}

response of the wind turbine fins based on wind speed and the angle of release of the wind turbine fins [4].

After the video capture process is complete, the video is processed on the tracker software. In this software you can see the phenomenon of the fin response to the direction of the wind, which is poured in the graphical form [5]. After processing the video, the data obtained from the tracker software is reprocessed in the sigmaplot software. Later on, this software can see a comparison of the responses of each type of fin. The research method used this time is an experimental method, where we make and test each tail fin to determine which tail fin is best for use in wind turbines based on its damping effect.

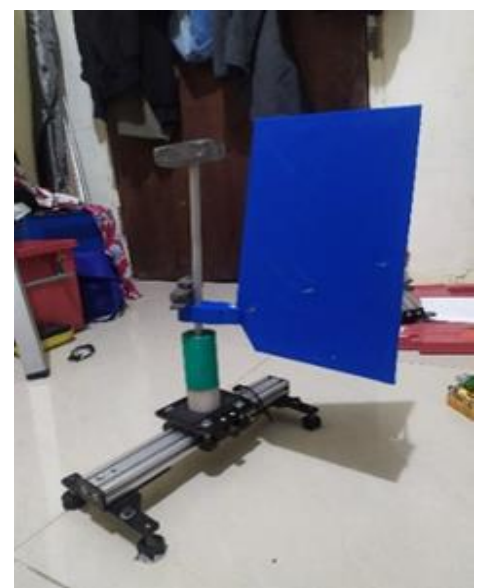

Figure 1. Wind turbine fin holder and fins 


\subsection{Directional Tail Fin Design}

In this study, there are several types of fins studied based on the existing literature, presented in Table 1.

\subsection{Data Collecting Procedure}

The following is the procedure for collecting data in the research process this time:

1. Prepare the fins that will be used in research.

2. Preparing the fin holder as a replacement medium for the turbine in the study.

3. Mounting and positioning the camera above the wind tunnel test section for video capture

4. Install the fins and weights on the stand and then place the stand on the bow that has been placed on the base of the test section

5. Close the test section door and turn on the wind tunnel with a speed of $1 \mathrm{~m} / \mathrm{s}$, measured using an anemometer.

6. Set the starting angle of the fins from an angle of $5^{\circ}$, after the wind speed in the wind tunnel stabilizes with the vibrations starting to disappear, release the fins at the same time as starting the recording through the camera.

7. Repeats step 5 to a speed of $5 \mathrm{~m} / \mathrm{s}$.

8. Repeat step 6 until the angle is $30^{\circ}$.

The video data that is processed in the tracker software can be seen in Figure 2.

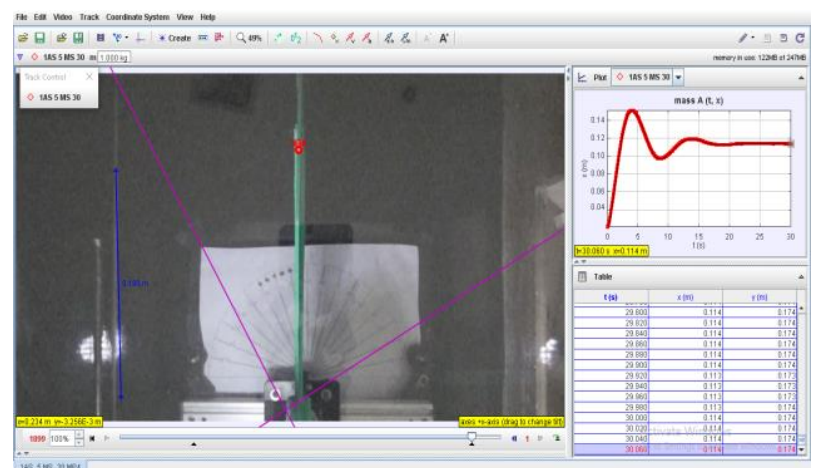

Figure 2. Analog to digital process

\section{RESULTS AND DISCUSSION}

Based on this research, data can be generated in the form of graphs which will be analyzed and compared based on previous research that has been done. Figure 3 is carried out at a wind speed of $5 \mathrm{~m} / \mathrm{s}$ with a wind turbine fin release angle of $30^{\circ}$, and the waves of each type of fin above are used as comparisons to determine the best kind of fin based on the damping effect [3].

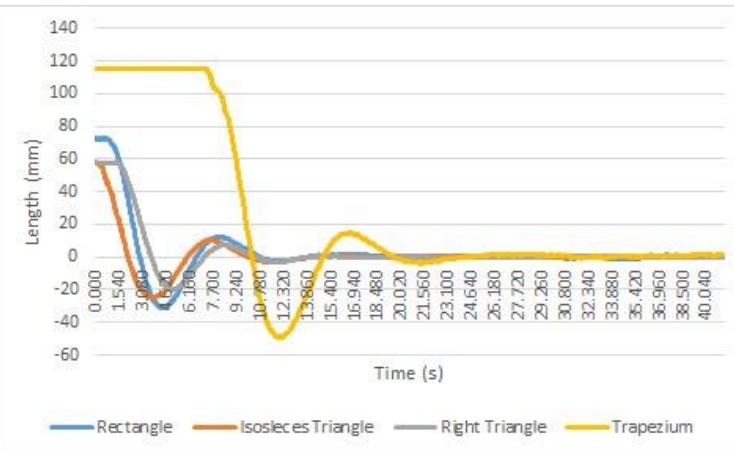

Figure 3. Graph of previous research fins (2019)

Table 3 forms figure 3, where we can determine the number of waves generated, the amplitude, and the Attenuation Time.

Table 2. Table of Previous Test Data

\begin{tabular}{|l|c|c|c|}
\hline \multicolumn{1}{|c|}{ Fin } & $\begin{array}{c}\text { Number } \\
\text { of waves }\end{array}$ & $\begin{array}{c}\text { Ampli- } \\
\text { tude }(\mathrm{m})\end{array}$ & $\begin{array}{c}\text { Time } \\
(\mathrm{s})\end{array}$ \\
\hline Rectangle & 1.5 & 0.0123 & 14.6 \\
\hline Isosceles Triangle & 2 & 0.00995 & 18.98 \\
\hline Isosceles Triangle & 1.5 & 0.00697 & 13.4 \\
\hline Trapezoid & 1.5 & 0.0145 & 18.64 \\
\hline
\end{tabular}

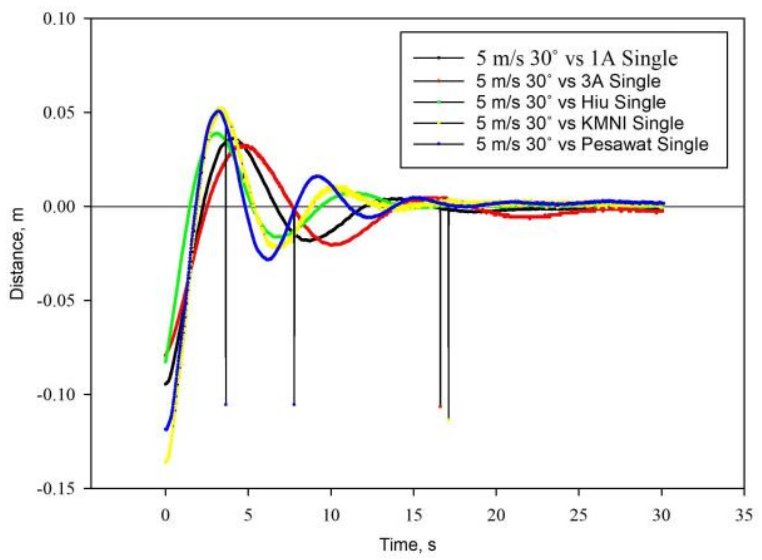

(a) single fin 


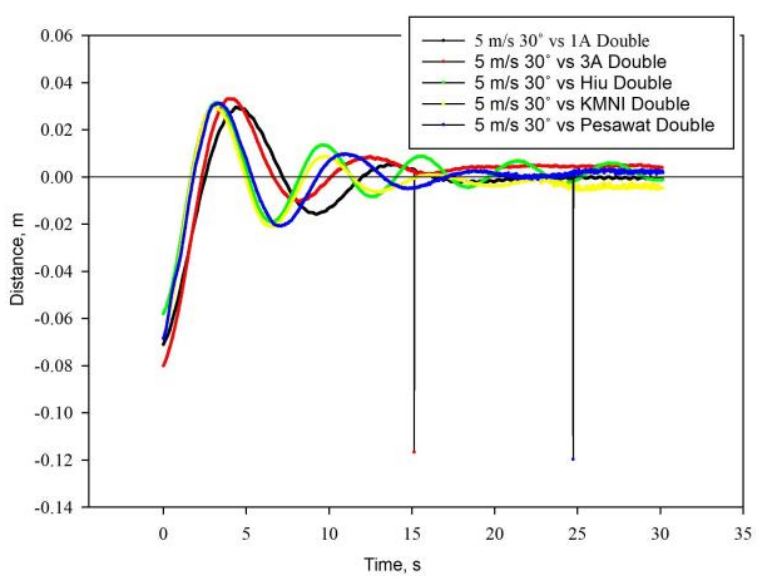

(b) double fin

Figure 4. Single fin research graph

The graphic above was obtained in research with a wind speed of $5 \mathrm{~m} / \mathrm{s}$ and a wind turbine fin angle of $30^{\circ}$.

Table 3. Table of single fin research results

\begin{tabular}{|c|c|c|c|}
\hline Fin & $\begin{array}{c}\text { Number of } \\
\text { waves }\end{array}$ & $\begin{array}{c}\text { Amplitude } \\
(\mathrm{m})\end{array}$ & $\begin{array}{c}\text { Time } \\
(\mathrm{s})\end{array}$ \\
\hline $1 \mathrm{~A}$ & 2 & 0.0353691 & 17.1 \\
\hline $3 \mathrm{~A}$ & 2 & 0.0314 & 26.21 \\
\hline Shark & 1.5 & 0.0382882 & 18.2 \\
\hline KMNI & 2.5 & 0.051339 & 17.68 \\
\hline Airplane & 3 & 0.0511713 & 19.35 \\
\hline
\end{tabular}

In Table 3, the results of this study are data on the number of waves, amplitude, and the attenuation time of each wind turbine fin shape.

Table 4. Table of double fin research results

\begin{tabular}{|c|c|c|c|}
\hline Fin & $\begin{array}{c}\text { Number of } \\
\text { waves }\end{array}$ & $\begin{array}{c}\text { Amplitude } \\
(\mathrm{m})\end{array}$ & $\begin{array}{c}\text { Time } \\
(\mathrm{s})\end{array}$ \\
\hline $1 \mathrm{~A}$ & 1.5 & 0.0315495 & 17.8 \\
\hline $3 \mathrm{~A}$ & 1.5 & 0.0338075 & 19.6 \\
\hline Shark & 3.5 & 0.035092 & 29.32 \\
\hline KMNI & 2 & 0.0305334 & 26 \\
\hline Airplane & 2.5 & 0.0318318 & 21.4 \\
\hline
\end{tabular}

In Table 4, the results of this study are data on the number of waves, amplitude, and the attenuation time of each wind turbine fin shape at a speed of $5 \mathrm{~m} / \mathrm{s}$ and a test angle of $30^{\circ}$. Two factors determine the best shape of the tail fin guiding the wind turbine: the least number of waves and the smallest amplitude. This is based on research entitled A Catalog of Tail Fin Shapes for Small
Wind Turbines that K.Kwan and Team have carried out. However, in this study, one additional factor was added to determine the best guiding tail fin based on its damping effect, namely the attenuation time of the fin $[3,10]$.

From the five types of single fins tested, we can see that the 1A single fin is better than the other four types of fins. The three factors that can determine the best $1 \mathrm{~A}$ fin are the least number of waves, the lowest amplitude, and the fastest attenuation time. So from the results of this study, it was found that the $1 \mathrm{~A}$ fin can be used as a further reference to be made as a fin that will be used in the turbine.

\section{CONCLUSION}

Based on this research, each type of fin is manufactured with an aspect ratio of 1.4 area, and the area used is $0.042 \mathrm{~m} 2$. I was judging from the three factors that determine that the best fin type is based on its damping effect: the least number of waves, the lowest amplitude, and the fastest attenuation time. Thus, the 1A Single fin is the best fin based on its damping effect with an average number of waves at each speed, an angle of release of 1.1 waves, an average amplitude of $0.014591609 \mathrm{~m}$, and a damping time of $16.16321429 \mathrm{~s}$.

\section{REFERENCES}

[1] T. P. S. Erwin Erwin, Adi Surjosatyo, Sakti Nurfuadi, Slamet Wiyono 2019 Performance investigation of dual shaft hybrid vertical turbines using directional fins Eastern-European Journal of Enterprise Technologies 5 No. 8 (101)

[2] B. Shahizare, N. Nik-Ghazali, W. T. Chong, S. Tabatabaeikia, N. Izadyar, and A. Esmaeilzadeh 2016 Novel investigation of the different Omni-direction-guide-vane angles effects on the urban vertical axis wind turbine output power via three-dimensional numerical simulation Energy Conversion and Management 117 pp. 206-217

[3] D. H. W. P.R. Ebert 1995 On the dynamics of tail fins and wind vanes Journal of Wind Engineering and Industrial Aerodynamics 56

[4] I. Neunaber, M. Hölling, J. Whale, and J. Peinke 2021 Comparison of the turbulence in the wakes of an actuator disc and a model wind turbine by higherorder statistics: A wind tunnel study Renewable Energy 179 pp. $1650-1662$

[5] E. Erwin, T. P. Soemardi, M. Y. N Ikhsan, and K. Nugraha 2019 Reduces blade shaft deflection with improved mount design to increase vertical hybrid wind turbine performance IOP Conference Series: Materials Science and Engineering 673 p. 012119 
[6] H. Z. Venkatesh Singamsitty 2017 Tail shape design of boat wind turbines International Journal Of Engineering Research \& Technology (IJERT) 06 no. Issue

[7] Y. Yulianto, E. Mandayatma, and B. Priyadi 2020 Study of comparison of tail wind turbines in wind power plants IOP Conference Series: Materials Science and Engineering 732, p. 012054

[8] J.Wieringa 1967 Evaluation and design of wind vanes Journal of Applied Meteorology 6

[9] R. Exwan 2017 Analisis kestabilan aerodinamika pada rudder pesawat terbang $\mathrm{n} 2 \mathrm{xx}$ pada kondisi left engine inoperatif(lei) Jurnal ROTOR 3

[10] K. Kwan et al 2011 A catalogue of tail fin shapes for small wind turbines 30th ISES Biennial Solar World Congress 2011 SWC 20116 pp. 5038-5047 